\title{
ANTHELMINTIC ACTIVITY OF HYDRO-ALCOHOLIC EXTRACTS OF CURCUMA LONGA, ZINGIBER OFFICINALE
}

Dr. N. Dora babu', Dr. Yahya yahya zaki fareed², Dr. Jasim Shihab Sultan ${ }^{3}$

\& Dr. Hamid Ghaffoori Hasan 4

\author{
1, 2 Faculty of Pharmacy, Uruk University, Baghdad, Iraq. \\ ${ }^{3}$ Faculty of Sciences, Alhadi University, Baghdad, Iraq. \\ ${ }_{4}^{4}$ Faculty of Pharmacy, Komar University of Science and Technology, Sulaymania, Iraq.
}

(Received on Date: 24th May 2020 Date of Acceptance: $5^{\text {th }}$ June 2020 Date of Publish: 01 st July 2020)

\section{Email: ndorababu81@gmail.com}

\begin{abstract}
Hydro-alcoholic extracts of Curcuma longa, Zingiber officinale and combination of Curcuma longa and Zingiber officinale rhizome extracts (1:1) were evaluated for their anthelmintic activity using Pheretima posthuma model. Three concentrations (10, 20 and $50 \mathrm{mg} / \mathrm{ml}$ ) of each extracts were used for this study which involved the determination of time of paralysis (vermifuge) and time of death (vermicidal activity) of the worms. Extracts obtained from both rhizomes not only paralyzed but also killed the earthworms. Among the two drug extracts, Curcuma longa showed maximum vermifuge activity at the concentration of $50 \mathrm{mg} / \mathrm{ml}$. Maximum vermicidal activity was shown in Zingiber officinale extract at the concentration of $50 \mathrm{mg} / \mathrm{ml}$. Combination of hydro-alcoholic rhizome extracts of Curcuma longa and Zingiber officinale also showed a significant anthelmintic activity. Observations were comparable with the standard drug at concentration of $20 \mathrm{mg} / \mathrm{ml}$. On the basis of the observations, it is concluded that both Curcuma longa and Zingiber officinale rhizomes extracts bearing a potential anthelmintic property
\end{abstract}

Keywords: Anthelmintic activity, Curcuma longa, Zingiber officinale, Pheretima posthuma. 


\section{INTRODUCTION}

Helminthes are the most common infections in man, affecting a large proportion of the world's population. Parasitic diseases may cause severe morbidities including lymphatic filariasis (a cause of elephantiasis), onchocerciasis, and schistosomiasis 1-2. Development of resistance to most of commercially available anthelmintic became a severe problem worldwide 3 .

Curcuma longa and Zingiber officinale rhizomes are rich for phytoconstituents viz. alkaloids, saponins, flavonoids, terpenes and steroids. These drugs are widely used in the treatment of different ailments in the Indian system of medicine.

Curcuma longa Linn. (Zingiberaceae) is commonly known as "Haldi" in Hindi, is a perennial plant having a short stem with large oblong leaves. It bears ovate pyriform or oblong, ovate or cylindrical rhizomes, which are often branched and brownish-yellow in color. Externally the drug is yellowish brown in color with characteristic odour and slightl pungent bitter in taste. Root scars and annulations are present on the surface of the rhizome. The fracture is horny and internal surface is orange in color. Its oil has a great importance in medicine. It contains of essential oil (5\%), alkaloid, starch grain, yellow matter curcumin (5\%) a polyphenol, which is the active substance of turmeric. Its systematic chemical name is $\quad(1 \mathrm{E}, \quad 6 \mathrm{E})$-1,7-bis(4-hydroxy-3methoxyphenyl)-1,6-heptadiene-3,5-

dione. It also contains turmeric oil (5-8\%), coporioc acid $(1 \%)$ as a free acid and veleric acid $(0.1 \%)$ as combined acid. It is used as analgesic, antibacterial, antioxidant, expectorant and flavouring agent. The rhizomes are used for the treatment of inflammation as a household remedy on empirical basis 4 . It is commonly cultivated in Ceylon, Belgium, Indonesia, France, and in South India and Bengal 5.

Zingiber officinale Linn. (Zingiberaceae), commonly known as "Adrak", is an herbaceous rhizomatous perennial plant, reaching up to $90 \mathrm{~cm}$ in height under cultivation. Rhizomes are aromatic, thick lobed and pale yellowish in color. Leaves are long and 2-3 cm broad with sheathing bases, simple, alternate, distichously narrow, oblong and lanceolate. The blades are gradually tapering to a point. The herb develops several lateral shoots in clumps which begin to dry when the plant matures. Inflorescence is solitary, lateral radical, pedunculate, oblong and has cylindrical spikes. Flowers are rare, rather small, calyx superior, gamosepalous, three toothed and open splitting on one side. Corolla is of three sub equal oblong to lanceolate connate greenish segments 6. It mainly contains up to $3 \%$ of volatile oil, a mixture of 24 constituents containing monoterpenoid fraction ( $\beta$ - phelladrene, cineol, and citral). and sesquiterpenoids ( $\beta$-sesquiphellandrene, bisabolene and farnesene), with (-)-zingiberene. It also contains $5-8 \%$ resinous matter, starch and mucilage. It is reported to have antioxidant, analgesic and antipyretic properties 7-9. Ginger oil has been shown to prevent skin cancer in mice. The gingerrols, an active constituent of ginger oil has demonstrated to kill ovarian cancer cells. The major world producers of Zingiber officinale are Piji, India, Nigeria, Sierra Leone and China. Based on the 
traditional uses and scientific reports, both plant extracts were selected to evaluate their anthelmintic activity using Indian earthworm as model.

\section{MATERIALS AND METHOD}

\section{Plant materials}

Rhizomes of Curcuma longa and Zingiber officinale were collected from botanical garden of the department and authenticated from Department of Botany, S.V.University, Tirupati, Andhra Pradesh, India.

\section{Drug and chemicals}

The following drugs and chemicals were used:

Piperazine citrate (Pankaj Medicos), Sodium chloride (Himedia), Ethanol (Qualigens).

\section{Preparation of extract}

The collected plant material (Rhizomes) of Curcuma longa and Zingiber officinale were washed thoroughly in water, cut into small pieces and air dried for 2 weeks at 35-40 OC. Extraction was done by using Soxhlet apparatus with $70 \%$ ethanol (hydro-alcoholic) as solvent. The extracts were concentrated under reduced pressure, dried and stored at $4 \mathrm{OC}$ in air tight containers for further studies.

\section{Preliminary phytochemical screening}

Phytochemical screening was carried out on Curcuma longa and Zingiber officinale rhizome extracts which revealed the presence of alkaloids, saponins, flavonoids, terpenes and steroids 10.

\section{Test organism}

Indian adult earthworms (Pheretima posthuma) collected from the botanical garden of the department and washed with normal saline. The earthworms of 3.5 $\mathrm{cm}$ in length and $0.1-0.2 \mathrm{~cm}$ in width were used for all the experimental protocol due to their anatomical and physiological resemblance with the intestinal roundworm parasites of human beings 11- 12 .

\section{Anthelmintic activity}

The anthelmintic activity of hydroalchoholic extracts of Curcuma longa and Zingiber officinale was carried out by methodology followed by John et al; 2009 13. and Ajayieoba et al; 2001 14. The ethanolic extracts were suspended in normal saline to prepare 10,20 and 50 $\mathrm{mg} / \mathrm{ml}$ concentrations. Piperazine citrate (20 $\mathrm{mg} / \mathrm{ml}$ ) was used as the standard drug. All the extracts and drug solution were freshly prepared before starting the experiment. Eleven groups with six earthworms in each were placed into $10 \mathrm{ml}$ of desired formulations as following: vehicle (normal saline), Piperazine citrate (20 $\mathrm{mg} / \mathrm{ml}$ ), and three sets of three different groups were treated with extracts of respective concentration. Observations were made for the time until the paralysis and death of an individual worm. The paralysis was said to occur when the worms were not able to move even in normal saline. Death was concluded when the worms lost their motility followed with fading away of their body colors 15. Results are shown in Table-1. 


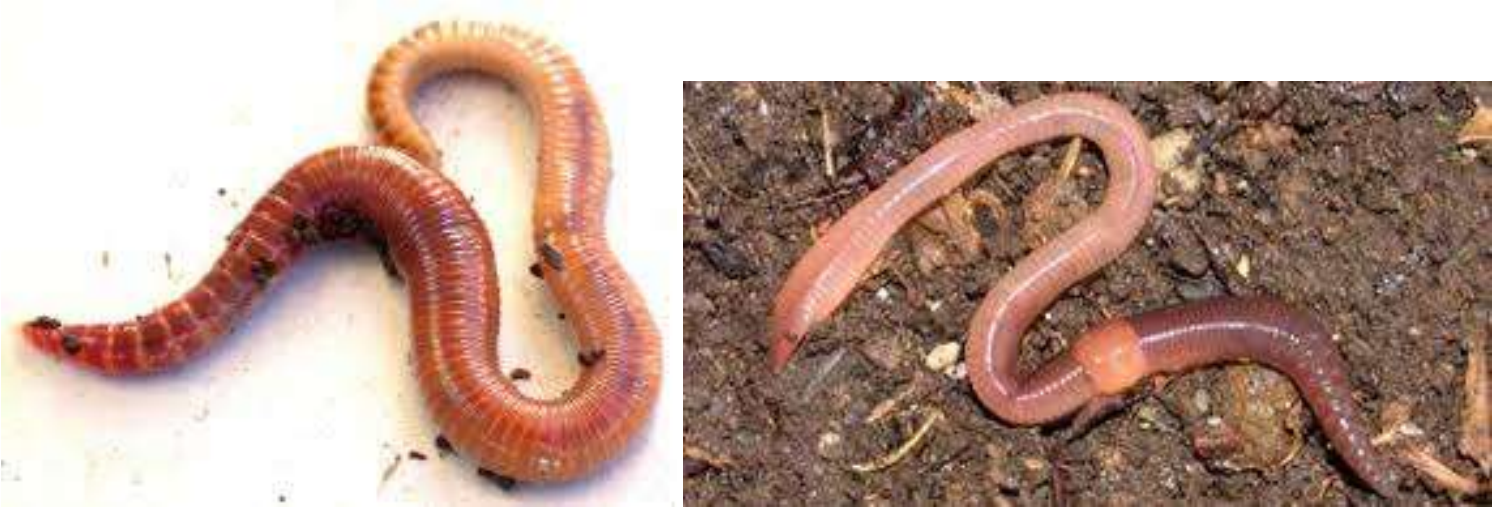

Adult Earth warms

Table 1: Anthelmintic activity of Curcuma longa and Zingiber officinale

\begin{tabular}{llll}
\hline Plant extract & Conc.(mg/ml) & $\begin{array}{l}\text { Time taken for } \\
\text { paralysis(min) }\end{array}$ & $\begin{array}{l}\text { Time taken } \\
\text { for death (min) }\end{array}$ \\
& & & \\
\hline Vehicle control & $\bullet$ & $\bullet$ & $32 \pm 0.38$ \\
Curcuma longa & 10 & $10.4 \pm 0.20$ & $27.5 \pm 2.2$ \\
& 20 & $6.2 \pm 1.5$ & $16.1 \pm 1.2$ \\
& 50 & $4.6 \pm 0.8$ & $31.2 \pm 0.13$ \\
Zingiber officinale & 10 & $11.2 \pm 1.8$ & $26.3 \pm 2.8$ \\
& 20 & $7.0 \pm 1.7$ & $11.6 \pm 1.4$ \\
Curcuma longa + & 10 & $5.2 \pm 0.4$ & $31.8 \pm 0.12$ \\
Zingiber & 50 & $10.6 \pm 0.4$ & \\
officinale (1:1) & 20 & & $27 \pm 0.44$ \\
Piperazine citrate & 20 & $6.8 \pm 0.6$ & $16.3 \pm 0.32$ \\
& 50 & $4.8 \pm 0.4$ & $15.9 \pm 1.3$ \\
\hline
\end{tabular}




\section{RESULTS AND DISCUSSION}

The Preliminary phytochemical analysis showed the presence of alkaloids, saponins, flavonoids, terpenes and steroids in the extracts of Curcuma longa and Zingiber officinale. Curcuma longa extract at the concentration of $10 \mathrm{mg} / \mathrm{ml}$ showed the time of paralysis and death at $10.4 \mathrm{~min}$. and $32 \mathrm{~min}$. respectively. For concentration of $20 \mathrm{mg} / \mathrm{ml}$, the paralysis and the death time was found $6.2 \mathrm{~min}$. and $27.5 \mathrm{~min}$. respectively. At the concentration of $50 \mathrm{mg} / \mathrm{ml}$, time was 4.6 min. for paralysis and $16.1 \mathrm{~min}$. for death. While in Zingiber officinale extract at the concentration of $10 \mathrm{mg} / \mathrm{ml}$, the time of paralysis and death was found to be 11.2 min. and $31.2 \mathrm{~min}$. respectively. At concentration of $20 \mathrm{mg} / \mathrm{ml}$, it was $7.0 \mathrm{~min}$. for paralysis and $26.3 \mathrm{~min}$. for death. For concentration at $50 \mathrm{mg} / \mathrm{ml}$, the time of paralysis and death was $5.2 \mathrm{~min}$. and 11.6 min. respectively. In case of combination of both the plant extracts /Curcuma longa and Zingiber officinale), the time of paralysis and death was 10.6 min. and $31.8 \mathrm{~min}$. respectively at concentration of $10 \mathrm{mg} / \mathrm{ml}$. At concentration of $20 \mathrm{mg} / \mathrm{ml}$, the time of paralysis and death was 6.8 $\mathrm{min}$. and $27 \mathrm{~min}$. respectively and at 50 $\mathrm{mg} / \mathrm{ml}$ concentration, the time of paralysis and death was $4.8 \mathrm{~min}$. and 16.3 min. respectively. The observations with piperazine citrate showed that time of paralysis and death was $7.2 \mathrm{~min}$. and 15.9 $\mathrm{min}$. respectively for concentration at 20 $\mathrm{mg} / \mathrm{ml}$ ). It was observed that both ginger as well as turmeric hydro-alcoholic extracts showed a remarkable anthelmintic potential against intestinal parasitism. Amongst the both extracts, Curcuma longa showed better activity in combination with Zingiber officinale.
Anthelmintic activity of Curcuma longa was enhanced in the presence of Zingiber officinale. The anthelmintic activity of Zingiber officinale and Curcuma longa may be due to the synergetic effect of active phytoconstituents i.e. alkaloids, saponins, flavonoids, terpenes, steroids, etc. presenent in the extracts. Further, there is scope to evaluate the active principles of Curcuma longa and Zingiber officinale rhizomes for their anthelmintic activity to open the new door for natural anthelmintic.

\section{REFERENCES}

1. Bundy DA, Immunoepidemiology of intestinal helminthic infection I: The global burden of intestinal nematode disease.

2. Tagboto S and Townson S, Antiparasitic properties of medicinal and other naturally occurring products. Adv. in Parasitol. 2001; 50:199-295.

3. Waller PJ, The future of anthelmintics in sustainable parasite control programme for livestock. Helminthologia. 2003; 40: 97102.

4. Mujumdar AM, Naik DG, Dandge CN and Puntambekar HM, Anti- inflammatory activity of Curcuma amada roxb. in albino rats. Indian Jour. Pharmacol. 2000; 32:375- 377.

5. Jain S, Shrivastava S, Nayak $S$ and Sumbhate S, Plant Review. Recents trends in Curcuma longa Linn. Phcog. Rev. 2007; 1:119-128. 
6. Schavenberg P, Paris F, Guide to Medicinal Plants, Keats Publishing, New Canaan: CT, 1977.

7. Suekawa M, Ishige A, Yuasa K, Sudo K, Aburada $M$ and Hosoya $E$, Pharmacological studies on ginger Linn. Pharmacological action of punget constituent, (6)- gingerol and (6)-shogol. J. Pharmacobiodyn. 1984; 7:836-848.

8. Mascolo N, Jain R, Jain SC, and Capasso $\mathrm{F}$, Ethnopharmacologic Investigation of ginger (Zingber officinale). Jour Ethnopharmacol. 1989; 27:129-140.

9. Jana U, Chattopadhyay RN and Shaw BP, Preliminary studies on anti-inflammatory activity of Zingber officinale Rosc., Vitex negundo Linn and Tinospora cordifolia (Willid) Miers in albino rats. Indian Jour. Pharmacol. 1999; 31: 232-233.

10. Evans WC, Trease and Evans Pharmacognosy. 13th Ed. English Languagae Book Society, Baillere Tindall London: 1999; 327- 536.

11. Thorn GW, Adams RD, Braunwald E, Isselbacher KJ and Petersdrof RG, Harrison's Principles of Internal Medicine. In: Mcgraw Hill Co., New York: 1977; 10881089.

12. Vigar Z, Atlas of Medical Parasitology. In: 2nd ed. P.G. Publishing House, Singapore. 1984; 216-217.

13. John J, Mehta A, Shukla S, Mehta P, A report on anthelmintic activity of Cassia tora leaves. Songklanakarin Jour. Sci. Tech. 2009; 31, 3:269-271.

14. Ajaiyeoba EO, Onocha PA, Olarenwaju OT, In-vitro anthelmintic properties of 2020 July Edition / www.jbino.com | Innovative Association
Buchholzia coriaceae and Gynandropsis gynandra extract. Pharm. Biol. 2001; 39:217- 20.

15. Girme AS, Bhalke RD, Ghogare PB, Tambe VD, Jadhav RS and Nirmal SA., Comparative In vitro Anthelmintic activity of Mentha piperita and Lantana camara from Western India. Dhaka University Jour. Pharm. Sci. 2006; (5) 12: 5-7

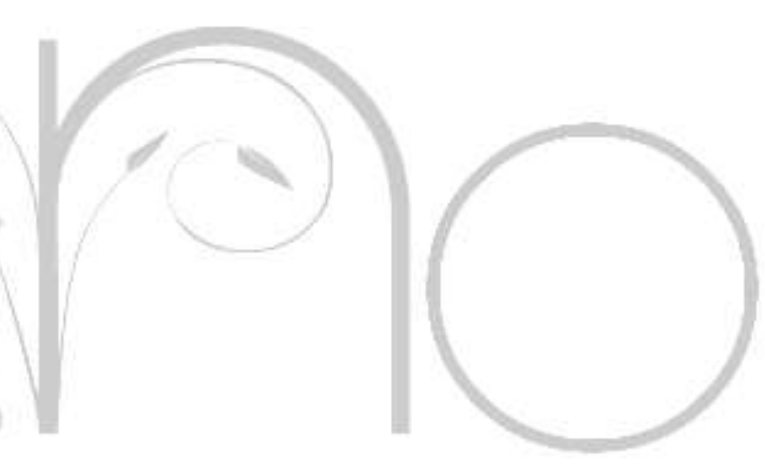

